\title{
Tarihi Yapının Müzeye Dönüştürülmesi Çalışmalarına Yönelik bir Tehlike ve Önlem Değerlendirmesi: Çorum Müzesi Örneği*
}

\section{Özet}

Çalışma kapsamında tarihi yapıdan müzeye dönüştürülmüş olan Çorum Müzesi'nin kısa tarihçesi, yapısal ve mekânsal özellikleri ile müzede yürütülen restorasyon ve teşhir tanzim çalışmaları incelenmiş, bu çalıșmaları tehlike ve önlem değerlendirmesi yapılmışsır. Çalışma hazırlanırken literatürdeki rehber yayın ve standartlar araştırılmıs, müze müdürlüğ̈̈, bağlı olduğu kurum ve ilgili kurumlarda bilgi ve belge araștırması, yerinde gözlem ve yetkililerle mülakatlar gerçeklestirilmistir. Hazırlanan tehlike ve önlem değerlendirme tabloları ile, tarih yapıda risk olușturabilecek tehlikeler, tehlike kaynakları ve bunlara yönelik alınan/alınması gereken önlemler iliskilendirilerek bundan sonraki çalısmalarda kolayılk sağlayacak bir yöntem olușturmak amaşlanmıştır. Müzz iliskling ve düzenleme asamalarnda sadece yapinın kendisinden kaynaklanacak tehlikeler değil kronumu

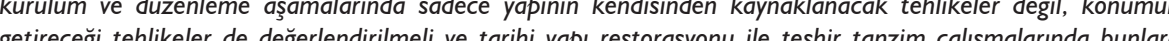
yönelik uy yonelk ur torihi yü

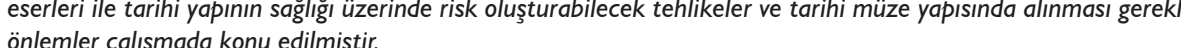

Anahtar Kelimeler: Çorum Müzesi, Risk Değerlendirmesi, Müzecilik

A HAZARD AND PRECAUTIONARY ASSESSMENT FOR CONVERSION OF THE HISTORICAL BUILDING INTO A MUSEUM: EXAMPLE OF ÇORUM MUSEUM

\section{Abstract}

Within the scope of the study, the brief history, structural and spatial fe atures of the Çorum Museum, which was transformed from a historical building into a museum, and the restoration and exhibition arrangement works carried out in the museum were examined, and the hazard and precautionary assessment of these works were made. While preparing the study, guideline publications and standards in the literature were searched, information and document research in the museum directorate, the affliated and related institutions, on-site observations and interviews with the authorities were carried out. With the prepared hazard and precaution assessment tables, it is aimed to constitute a method that will facilitate the future studies by correlating the dangers that may pose risks in the historical structure, the sources of danger and the measures taken / to be taken against them. During the stages of museum establishment and arrangement, not only the dangers arising from the building itself, but also the dangers of the location should be evaluated and practices should be made in the restoration works of historical building and exhibition arrangement works. As a contribution to the risk assessments where human health is a priority, the dangers that may pose a risk to the health of the museum artefacts and the historical structure, and the necessary measures to be taken in the historical museum structure are discussed in the study.

Keywords: Çorum Museum, Risk Assessment, Museology 


\section{Giriş}

Çalışma kapsamında tarihi yapıdan müzeye dönüştürülmüş olan Çorum Müzesi binasının kısa tarihçesi, yapısal ve mekânsal özellikleri ile müzede yürütülen restorasyon ve teşhir tanzim çalışmaları incelenmiş ve bu çaIışmalar eserlerin maruz kalabileceği tehlikeler ve bunlara yönelik alınan mimari önlemler açııından değerlendirmiştir. Çalışma hazırlanırken literatürdeki rehber yayın ve standartlar araştııılmış, müze müdürlüğü, bağlı olduğu kurum ve ilgili kurumlarda bilgi ve belge araştırması yapılmış, ayrıca yerinde gözlem ve yetkililerle mülakatlar gerçekleştirilmiştir. Hazırlanan tehlike ve önlem değerlendirme tabloları ile, müze olarak kullanılan tarihi yapılarda risk oluşturabilecek tehlikeler, tehlike kaynakları ve bunlara yönelik alınan/alınması gereken önlemler ilişkilendirilerek bundan sonraki çalışmalarda kolaylık sağlayacak bir yöntem oluşturması amaçlanmıştır.

Çorum Müzesi Kültür ve Turizm Bakanlığına bağlı bir devlet müzesidir. Korunması gerekli kültür varlığı olarak, mülga Gayrimenkul Eski Eserler ve Anıtlar Yüksek Kurulu'nun 08.12.1978 tarihli ve A-1458 sayılı kararıyla tescilli olan müze binası Çorum ili, Merkez, Gülabibey Mahallesi, Cengiz Topel Caddesi, No:153 adresinde yer almaktadır. Kadastral bilgileri 44 Pafta, 4136 Ada, 475 Parseldir (Görsel 1).

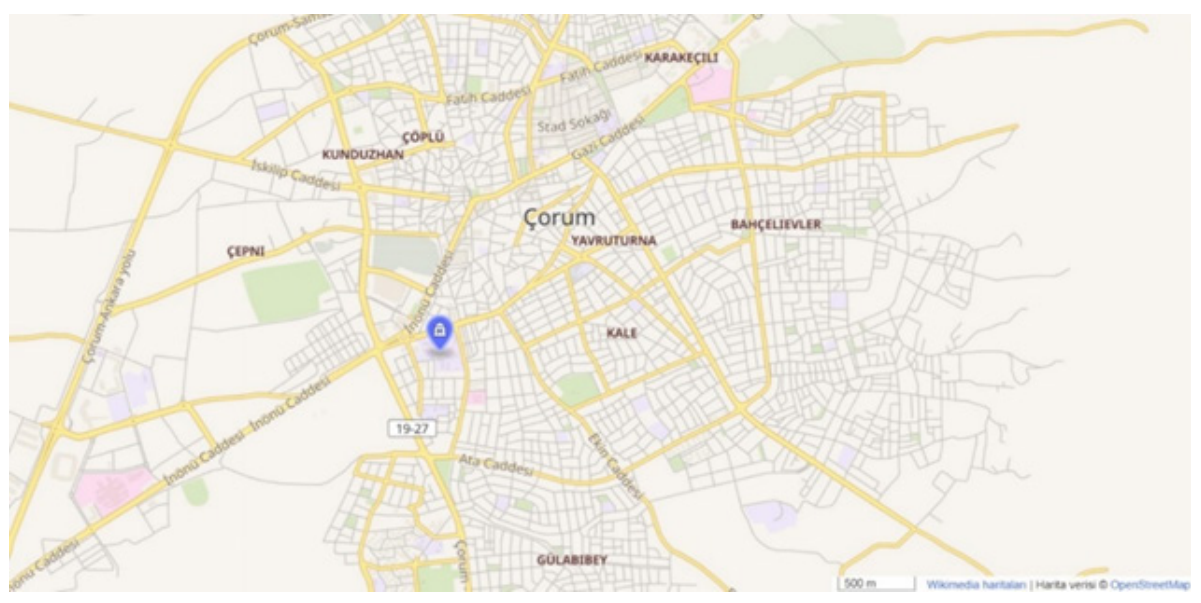

Görsel I. Çorum Müzesi'nin kentsel konumuna ilişkin harita'

Internet: Çorum Haritası. https://tr.wikipedia.org/wiki/\%C3\%87orum_M\%C3\%BCzesi\#/map/0 adresinden 18 Mayıs 202 I'de alınmiştır.
Hitit uygarlığının başkenti Hattuşa ile Alacahöyük, Şapinuva, Alişar gibi önemli Hitit yerleşimleri, Paeolitik dönemden Hatti, Frig, Roma, Bizans, Selçuklu ve Osmanlı gibi çeşitli uygarlıklara kadar zengin bir tarihi birikime sahip bir şehir olan Çorum'da 1900'lü yıllarda başlayan bilimsel kazılar Atatürk'ün talimatlarıyla başlatılan Alacahöyük kazısıyla önem ve yoğunluk kazanarak günümüze kadar ulaşmıştır. Bu kazılardan elde edilen önemli ve çok sayıda arkeolojik buluntular için 1968 yılından beri kullanılan müze binasında mekân yetersizliği ve çağdaş müzecilik gereksinimleri sonucun$\mathrm{da}$, yeni bir müze binası arayışına girilmiştir (Kültür Varlıkları ve Müzeler Genel Müdürlüğü [KÜVAM], 2021).

Günümüzde Çorum Müzesi olarak kullanılan yapı, hastane binası olarak tasarlanmış ve 1914 yılında inşası tamamlanmıştır. 1986 yılında müze olarak kullanılmak üzere Milli Eğitim Bakanlığından Kültür ve Turizm Bakanlığına devrine kadarki süreçte Ziraat Mektebi ve Makine Yüksek Okulu olarak da kullanılmıştır. 1988 yılında geçirdiği yangın sonucunda yapı büyük oranda zarar görmüştür. Restorasyon çalışmalarının tamamlanması ile 11.03.2003 tarihinde müze ziyarete açılmıştır (Görsel 2). ${ }^{2}$

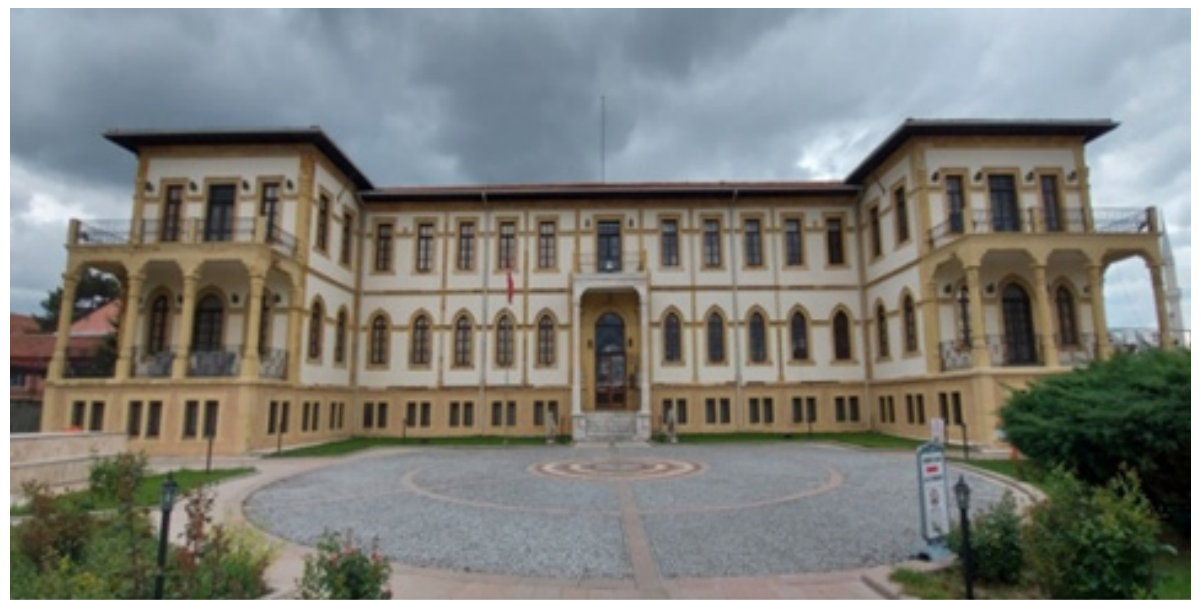

Görsel 2. Çorum Müze binası ${ }^{3}$

\section{Müze Binasının Yapısal Özellikleri ve Geçirdiği Müdahaleler}

Yapı bodrum kat dahil üç katlı olarak inşa edilmiştir. Özgününde taş yığma sistem ile inşa edildiği, kullanılan malzemenin sarı renkte kumtaşı olduğu,

${ }^{2}$ Internet: T.C. Çorum Valiliği resmi internet sitesi. Web: http://corum.gov.tr/corum-muzesi adresinden II Şubat 202 I'de alınmıştır.

${ }^{3}$ Kaynak gösterilmeyen grafik, çizim ve resimler yazara aittir. 
taş aralarında harç, duvarlar üzerinde sıva bulunduğu belirlenmiştir. Yapının müze olarak kullanımına yönelik rölöve, restitüsyon ve restorasyon projelerinin yapımına 1989 yılında başlanılmış ve hazırlanan projeler mülga Ankara Kültür ve Tabiat Varlıklarını Koruma Kurulunun 09.10.1990 tarihli ve 1397 sayılı kararı ile onaylanmıştır. Uygulaması 12 yıl süren restorasyon çalışmaları sırasında özgün beden duvarlarının korunarak iç duvarların ve zemin döşemelerinin çelik sistemi ile yeniden yapılandırıldı̆̆ı, iç duvar dolgusunun hafif ve gözenekli yapıya sahip gazbeton malzeme ile örüldüğü, ve temelde betonarme kullanıldığı elde edilen belgelerden ve yapı kullanıcıları ile görüşmelerden anlaşılmaktadır (Görsel 3) (KÜVAM, 2021).

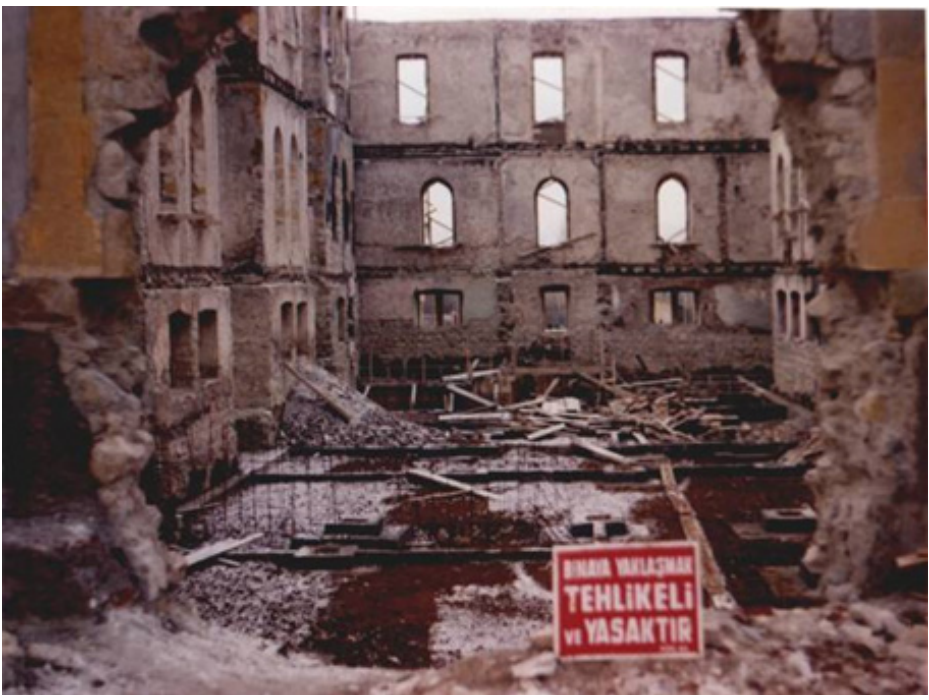

Görsel 3. Yangın sonrası müzenin görünümü (Çorum Müzesi Müdürlüğ̈̈ [ÇMM], 202I)

\section{Müze Binasının Mekânsal Özellikleri}

Yapı şehir merkezinde, caddeye bakan geniş bir bahçe içerisinde ayrık düzende inşa edilmiştir. Düz ve engebesiz bir arazi üzerinde 963 m2'lik bir alana yerleştirilen yapının toplam kullanım alanı 2900 m2' dir. Açık alan yüzölçümü ise 10.120 m2'dir. Dıștan dışa 25 × 50 m. ebatlarında olan ana kütle, doğu-batı istikametinde uzanmaktadır (Görsel 4) (KÜVAM, 2021). Ziyaretçi girişi kuzey yönündeki ön cepheden ve 7 basamaklı bir merdivenle sağlanır. Yapının doğu kanadı sergileme mekânlarına ayrılmıştır ve ziyaretçi girişinin solunda yer alan bu bölümde üç adet asma kat yapılmıştır (Görsel 5). Ziyaretçi girişinin sağında yer alan bölüm ise müzenin idarì kısımları ile sosyal etkileşim mekânları için kullanılmaktadır.

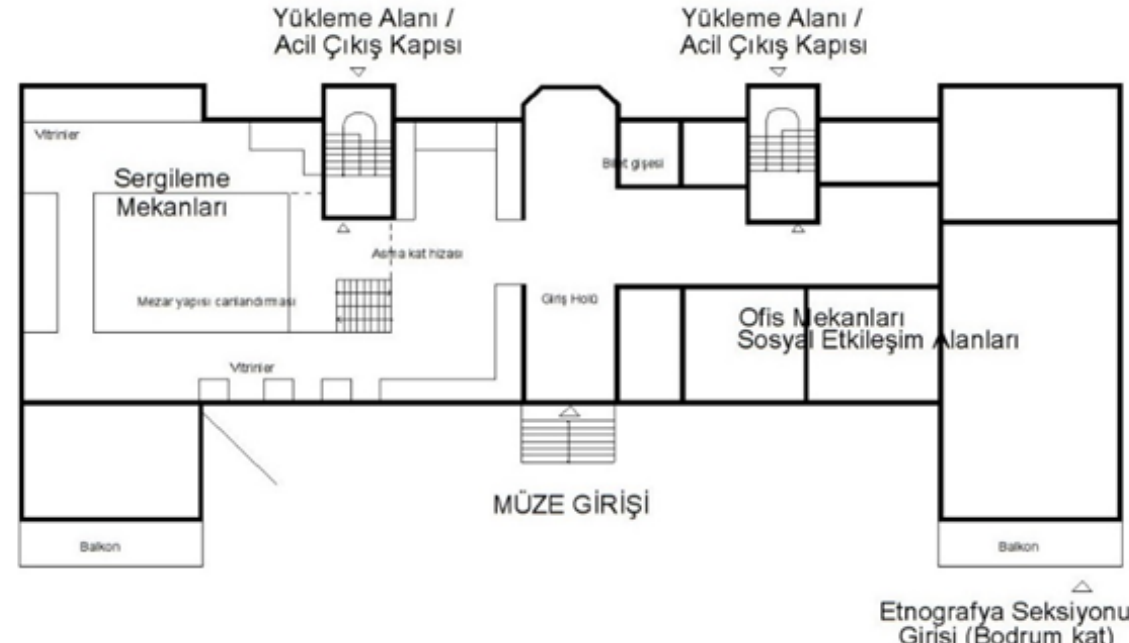

Görsel 4. Müze giriş katı plan şeması

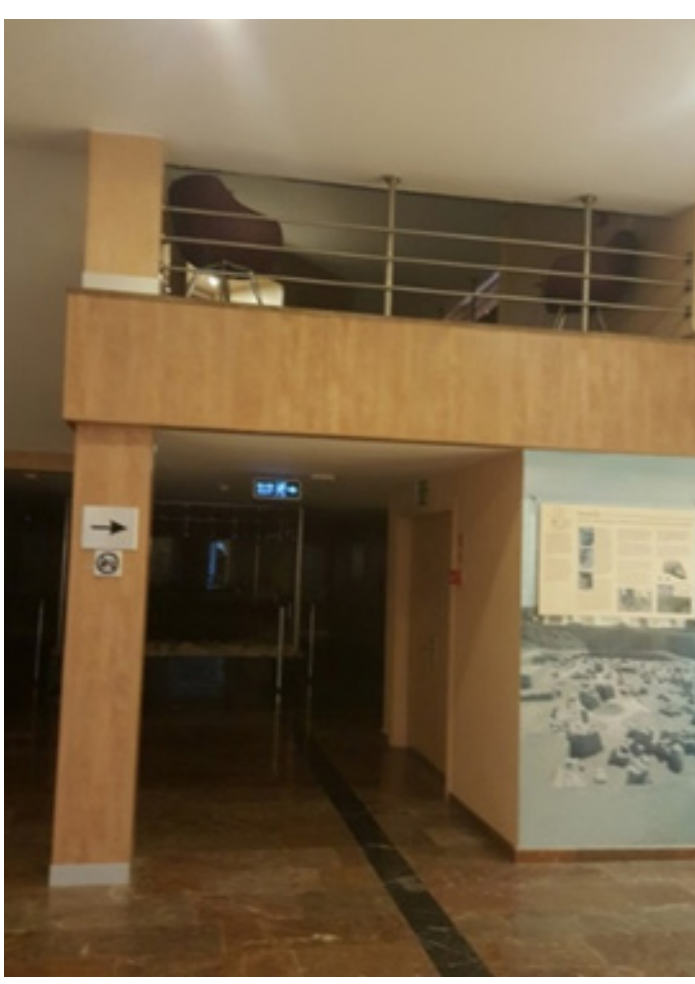

Görsel 5. Sergileme mekânında asma kat 
Binanın doğu ve batı kanatlarındaki kuzeye bakan çıkmalarda birinci katta kolonlu ve ikinci katta korkuluklu olmak üzere balkon kısımları bulunmaktadır. Giriş kapısının üzerinde de balkon kısmı mevcuttur. Güney cephesinde beş adet çıkma vardır. Bu çıkmaların ikisi yükleme alanı ve acil durum çıkış kapısı olarak kullanılmaktadır. Yapının pencere ve kapı açıklıklarına bakılacak olunursa, birinci kattaki açıklıkların kemerli olduğu, bodrum kat ve ikinci kattaki açıkıkların dikdörtgen formlu olduğu, ayrıca cephedeki açıklık oranının cephe uzunluğunun 1/3-2/3 oranı aralığında olduğu ve izdüşümlerin düşeyde düzenli olduğu gözlenmiştir.

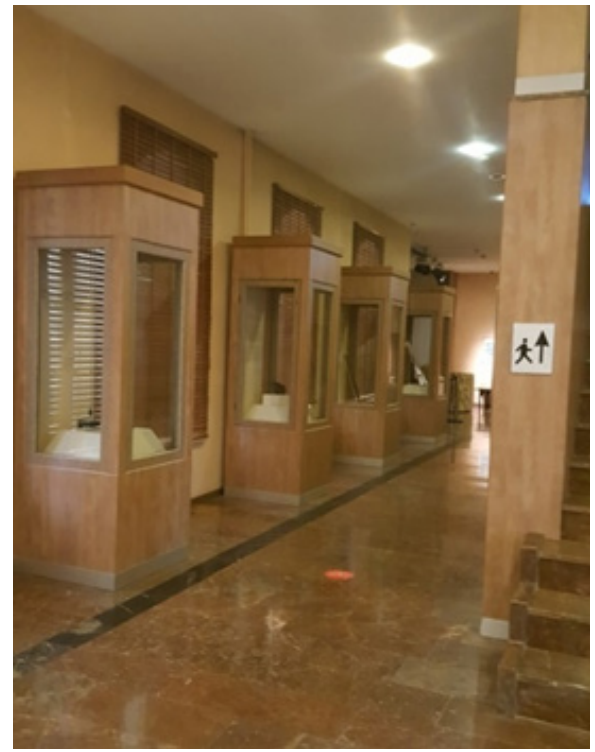

Görsel 6. Arkeoloji Seksiyonu

Eser sergilemesi birbirinden bağımsız girişleri olan Arkeoloji ve Etnografya Seksiyonlarında yapılmaktadır. Yapının giriş katının doğu kanadındaki Arkeoloji Seksiyonu'nda ilk katta Alacahöyük, Kuşsaray ve Büyük Güllücek kazılarından elde edilmiş Kalkolitik Çağ eserleri ile satın alma yoluyla müzeye alınan eserler vitrinler içerisinde sunulmaktadır (Görsel 6). Bu katın orta alanında Eski Tunç Çağı Alacahöyük prens ve prenses mezarı aslına uygun sekilde teșhir edilmektedir. Birinci asma katta bulla, mühür ve tabletler, ikinci asma katta Frig, Hellenistik, Galat ve Roma dönemi buluntuları bulunmaktadır. Üçüncü asma katta ise Roma dönemine ait cam eserler, altın ve gümüşsüs eşyaları, kandiller ve Bizans dönemine

${ }^{4}$ Internet: T.C. Çorum Valiliği resmi internet sitesi. Web: http://corum.gov.tr/corum-muzesi adresinden II Şubat 202I'de alınmıştır. ait eserler sergilenmektedir. ${ }^{4}$ Etnografya Seksiyonu, bodrum katta binanın batı kanadındaki çıkmanın kuzey cephesinden giriş yapılan L-formunda bir mekândır (Görsel 7, 8). Bu bölümde Çorum'a özgü leblebicilik, bakırclık ve kahvehane geleneğini yansıtan canlandırmalar ile Selçuklu ve Osmanlı dönemi el sanatlarından örnekler yer almaktadır.

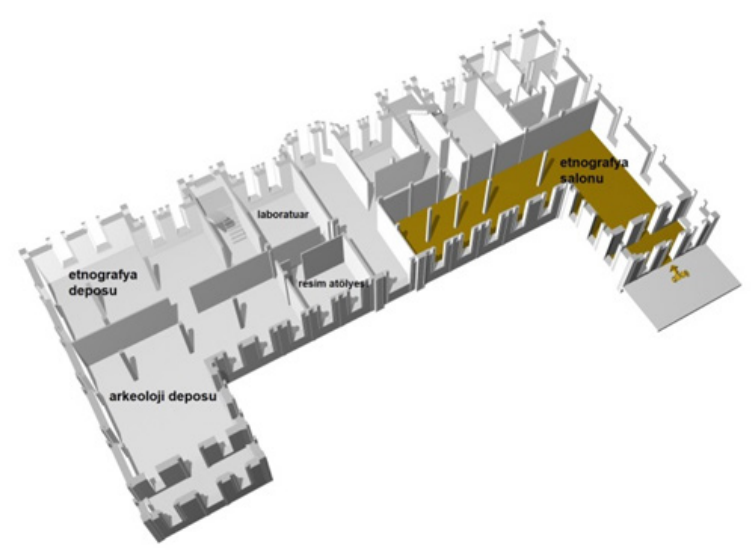

Görsel 7. Depolar ve Etnografya Seksiyonu (ÇMM, 202I)

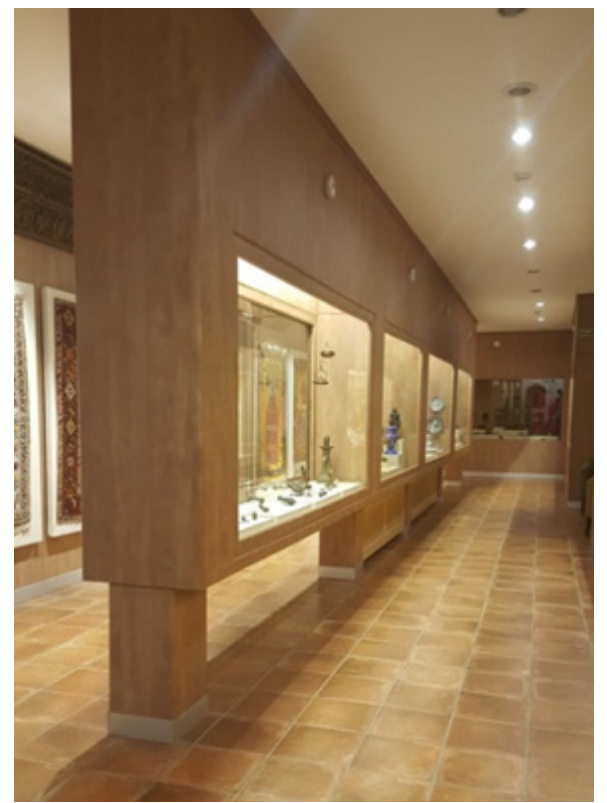

Görsel 8. Etnografya Seksiyonu 
Bodrum katta yer alan depolama mekânları, eser türlerine göre halı, kilim, tekstil gibi eserlerin bulunduğu etnografya deposu ve tablet ve sikke gibi eserlerin bulunduğu arkeoloji deposu olarak iki mekândır (Görsel 9). Depo mekânlarının yanında laboratuvar, resim atölyesi ve yedek depo mekânı bulunmaktadır.

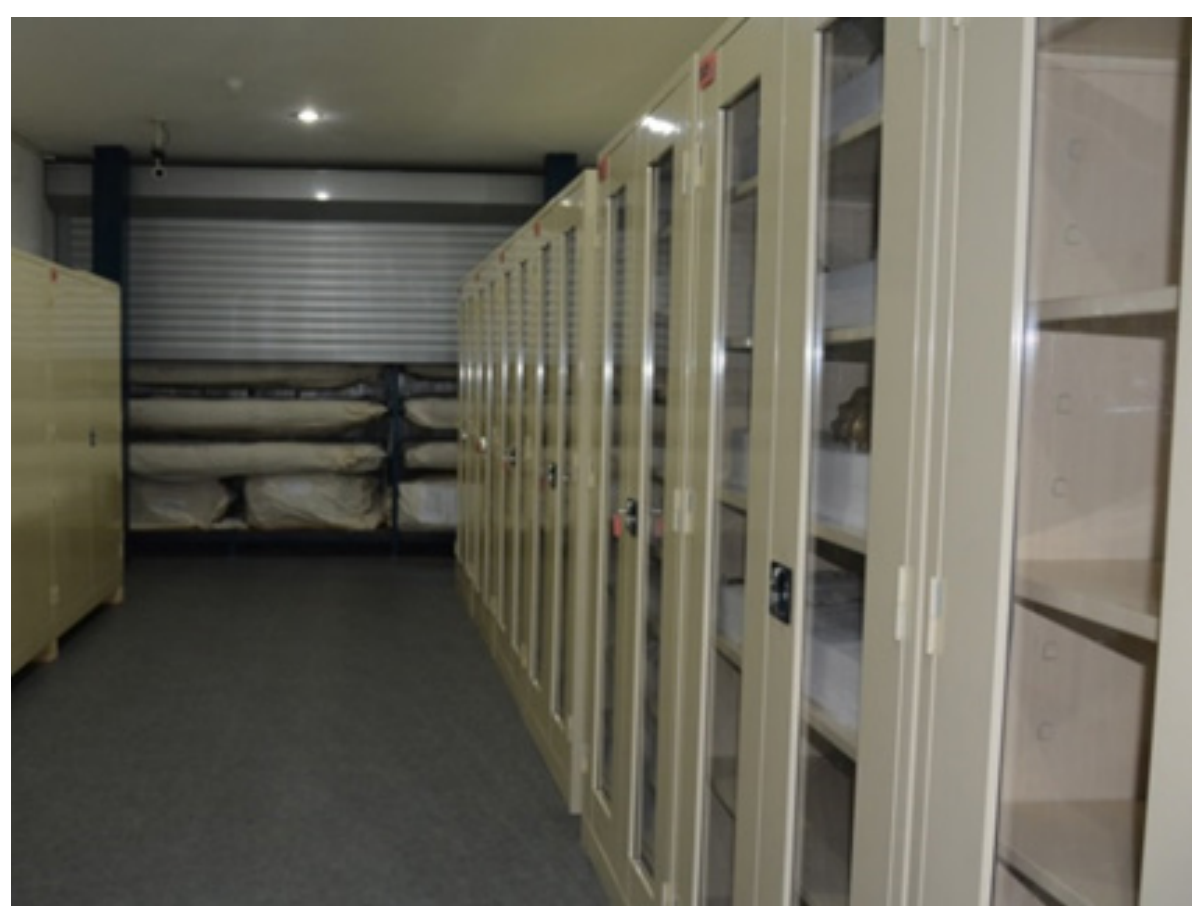

Görsel 9. Depo mekânı (ÇMM, 202I)

\section{Tartışma}

Müze binaları, gerek çevresel faktörlerden gerekse müze binalarının kendisinden kaynaklanan çeşitli tehlikeler barındırmaktadır. Bu tehlikeler eserlerde bozulmaya neden olabilecek olay ve durumlar ile aniden gelişen ve eserler üzerinde yıkıcı etkileri olan afetlerdir. Afet ve Acil Durum Yönetimi Başkanlığı (AFAD) tarafından aşağıdaki tanımlamalar yapılmışıı:

Afet: “Toplumun tamamı veya belli kesimleri için fiziksel, ekonomik ve sosyal kayıplar doğuran, normal hayatı ve insan faaliyetlerini durduran veya kesintiye uğratan, etkilenen toplumun baş etme kapasitesinin yeterli olmadığı doğa, teknoloji veya insan kaynaklı olay" (AFAD, 2014: 23)

Risk: "Bir olayın belirli koşul ve ortamlarda doğurabileceği can, mal, ekonomik ve çevresel gibi değerlerin kaybının gerçekleşme olasılığı" (AFAD, 2014: 128).

Tehlike: "Belirli bir zaman veya coğrafyada ortaya çıkarak yaşamı tehdit eden, toplumun sosyoekonomik düzen ve etkinliklerine, doğal çevreye, doğal, tarihi ve kültürel kaynaklara zarar verme potansiyeli olan doğa, teknoloji ya da insandan kaynaklanan fiziki olay ve olgu" (AFAD, 2014: 144).

Müzenin konumundan kaynaklanan tehlikeler içerisinde afetler, hırsızlık, vandalizm, insan kaynaklı yangın, su baskını, kirlilik, uygunsuz sıcaklık ve bağıl nem yer almaktadır. Doğal afetlerin yanı sıra, nükleer santral kazaları, endüstriyel kazalar gibi teknolojik veya asit yağışları, bina çökmesi, savaş hali gibi insan kökenli afetler de görülebilmektedir (Kadıoğlu, 2008: 6).

Müze binasında kaynaklanan tehlikeler içerisinde ise afetler, temas, darbe, titreşim ve benzeri fiziksel kuvvetler, hırsızlık, vandalizm, insan kaynaklı yangın, su baskını, zararlı, kirlilik, uygunsuz ışık, sıcaklık ve bağıl nem bulunmaktadır.

Tarihi yapıların, modern müze donanımları için gerekli elektrik, su tesisatları ve güvenlik sistemlerini kaldıracak bir altyapısı çoğunlukla bulunmamaktadır (Kocaeli, 2017: 53). Afet riski durumunda tarihi yapıların özgün değerlerinin yitirilmesi veya varlığın yok olması ihtimali söz konusu olduğundan afet öncesinde hazırlık yapılmasına dikkat edilmelidir (Zıvralı ve Cabbar, 2015:

169). Bir afet durumunda müzenin bulunduğu alana yardım ulaştırabilme durumu da sorgulanmalıdır (Roberts ve Hutchins, 2009/2016: 13).

Eski Çorum Müzesi eserleri için koruyucu ve çağdaş bir sergileme ve depolama ortamı sunamaz duruma geldiği için tarihi meslek yüksek okulu binası müze olarak kullanılmak üzere Kültür ve Turizm Bakanlığına devredilmiştir. Tarihi yapı 1988 yılında geçirdiği yangın ile büyük oranda yıkıma uğramış; ayrıca fonksiyonun müze olarak değiştirilmesi için çeşitli düzenlemeler gerekmiştir. Bu düzenlemelerde yapının özgün gabarisi korunmuş; çatı örtüsü, müze sergileme, depolama ve ofis mekânları, giriş holü, döșemeler, tavanlar, çevre drenajı, tesisat sistemi ve sıva uygulamaları yeniden yapılmıştır. 1989 yılı sonrasında başlayan restorasyon ve teşhir tanzime yönelik çalışmalar sonucunda 2003 yılında müze olarak kullanıma açılmıştır. 2005 yılında gerçekleştirilen çevre düzenlemesi ile açık alanda sergileme düzenlenmiştir. Bu kapsamlı değişikliklerin yanı sıra 20102020 yılları arasında müzenin sürekli olarak bakım ve onarım çalışmaları yapılmıştır (Görsel 10) (KÜVAM, 2021). 


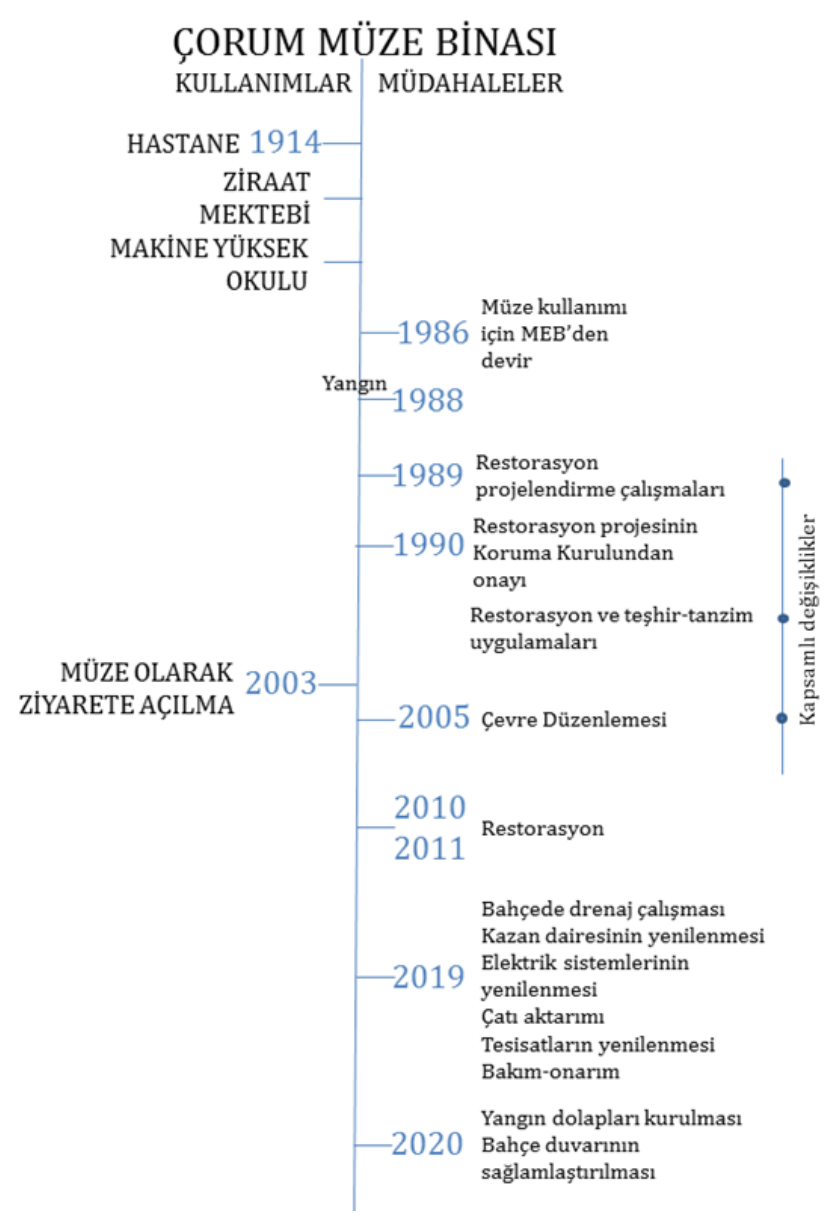

Görsel I0. Çorum Müzesi'nin Kullanım ve Müdahale Aşamaları

Bilgi ve belge araştırması ile 22.01.2021 tarihinde yapılan yerinde gözlem sonucunda elde edilen veriler ile yazar tarafından Tarihi Yapının Çorum Müzesine Dönüştürülmesine Yönelik Müze Konumu Kaynaklı Tehlike/Önlem Değerlendirme Tablosu (Tablo 1) ile Tarihi Yapının Çorum Müzesine Dönüştürülmesine Yönelik Müze Yapısı Kaynaklı Tehlike/Önlem Değerlendirme Tablosu (Tablo 2) oluşturulmuş ve sonraki bölümlerde sonuçları tartışılmaktadır.

\section{Tarihi Yapının Çorum Müzesine Dönüstürülmesine Yönelik Müze} Konumundan Kaynaklı Tehlike ve Önlemlerin Değerlendirilmesi

Çorum Müzesi'nin konumundan kaynaklanan deprem tehlikesi ele alındığında, tehlike sebepleri olarak toprağın türü, deprem bölgesinde yer alma ve sismik hareket varlığı konuları araştııılmıştır. Çorum Valiliği, Çevre ve Şehircilik Müdürlüğünden alınan bilgiye göre, müzenin bulunduğu bölgedeki zemin, orta-sıkı olarak tabir edilen Z3 zemin sınıfına dahildir (Doğruer, 2021). Buna ilaveten, Türkiye Deprem Tehlike Haritasında Çorum il merkezinin deprem yönünden düşük risk barındırdığı belirtilmektedir. Yapının bulunduğu zemine yönelik ayrıca bir etüd yapılmadığı arşiv bilgilerinden anlaşılmakla birlikte, yukarıdaki bilgiler ışığında müzenin konumuna bağIı olarak deprem yönünden yüksek risk barındırmadığı düşünülmektedir (KÜVAM, 2021).

Hırsızlık ve vandalizm tehlikesi ele alındığında, müzenin bulunduğu alanın suç oranı bakımında yüksek risk taşımaması yanında önlem olarak güvenlik sistemleri kurulduğu ve güvenlik personeli görevlendirmesi yapıldığ gözlenmiştir.

Müzenin konumundan kaynaklanan yangın tehlikesini değerlendirmek üzere kullanılacak veriler çevredeki binalar, mevsimsel şartlar ve yağış miktarı incelenerek elde edilmiştir (Milli Park Hizmeti, 2006: 54). Değerlendirme sırasında; müze etrafındaki genellikle kamu binası hizmetinde kullanılan binaların birbirinden uzak konumda bulundukları ve yapı malzemeleri bakımından yangın açısından yüksek risk taşımadığı tespit edilmiştir. Ayrıca, Çorum iline ait mevsim normallerine göre şehirdeki ortalama en yüksek sıcaklık temmuz ve ağustos aylarında $29^{\circ} \mathrm{C}$ civarında seyretmekte, ortalama en düşük sıcaklık ise ocak ayında $-4.3^{\circ} \mathrm{C}$, şubat ayında ise -3.4 ${ }^{\circ} \mathrm{C}$ olarak bildirilmektedir. Ortalama yağışlı gün sayısı yılda 100 gün civarındadır. Bu verilere bakılacak olursa, dış hava şartlarının çok yüksek veya çok düşük sıcaklıkta olduğu söylenemez. Yağışlı gün sayısının ise ortalama düzeyde olduğu belirtilebilir. Bu veriler ışı̆ıında, konumdan kaynaklı yangın riskinin düşük olduğu düşünülebilir; ancak önlem alınması tartışmasız gereklidir. Müzede manuel yangın söndürme sistemi bulunmakta; ayrıca yangın dolabı, yangın tüpü ve duman dedektörü kullanılmaktadır.

Yapıların bulunduğu alandan kaynaklanan su baskını tehlikesine eski bir dere yatağında bulunma; yağmur ve kar yağış miktarının fazlalığı veya değişkenlik sebep olabilmektedir (Kanada Koruma Enstitüsü, 2015). Çorum Müzesi'nin bulunduğu alanın dere yatağında yer almadığı anlaşılmışırı. Geçmişte gerçekleşmiş şiddetli meteorolojik olaylar araştıııldığında, Çorum'da 09.10.2003 tarihinde meydana gelen fırtınada Çorum Müzesi'nin çatısında çeşitli tahribatlar meydana gelmiş, sonrasında alçı sıva ve alçıpan asma tavanlarda yağmur ve kar sularının oluşturacağı akıntılara karşı gerekli uygulamalar yapılmıştır. 2019 yılında müzede gerçekleștirilmis olan drenaj çalışması ile su baskınına yönelik bir önlem alınmıştır (KÜVAM, 
2021). Yaşanmış şiddetli meteorolojik olayların uzmanlarca incelenerek bunların tekrarlaması muhtemel olup olmadığının ve muhtemel ise öngörülen zaman diliminin belirlenmesi yararlı olacaktır (Roberts ve Hutchins, 2009/2016: 15).

Yer kayması yönünden riske sebep olabilecek yumuşak veya gevşek toprak, heyelan bölgesinde yer alma Z3 zemin türüne sahip Çorum Müzesi yerleşimi için geçerli değildir.

Müzenin konumundan kaynaklanan kirlilik açısından inceleme yapıldığında; kirliliğe sebep olabilecek şekilde, yapının endüstriyel bir alanda yer almadığı ve çevresinde döşenmemiş yollar bulunmadığı; ancak yoğun trafiğe sahip bir bulvar üzerinde yer aldığı gözlemlenmiştir. Bulvardan geniş bir bahçeyle ayrılan bina için kirlilik tehlikesine yönelik olarak filtre kullanılmadığı belirlenmiştir (Görsel 11).

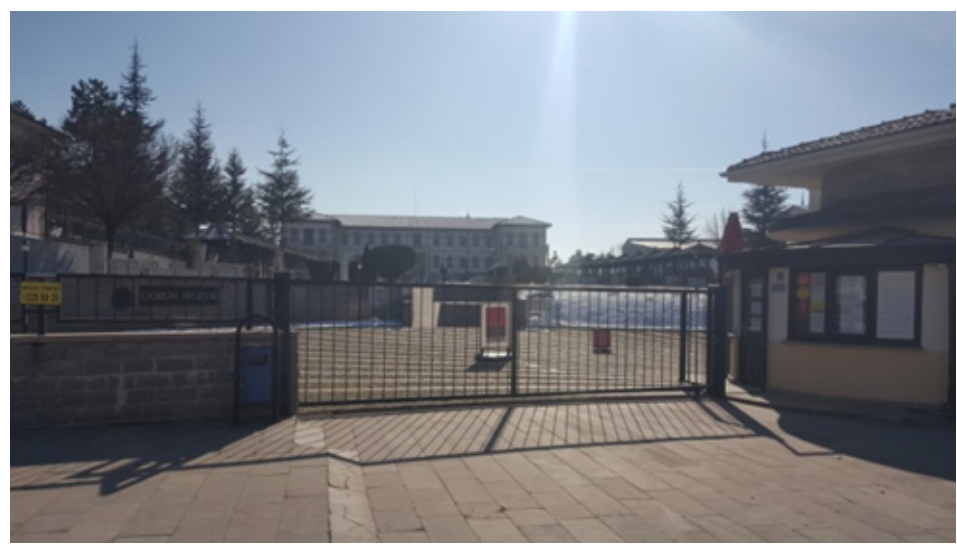

Görsel II. Çorum Müzesi bahçesi

Müzenin bulunduğu Çorum şehrinin mevsimsel şartları yapıda genel olarak uygunsuz sıcaklık tehlikesine sebep olmayacaktır. Yakın çevrede su kaynağı bulunmaması da uygunsuz bağıl nem tehlikesi oluşturmaması açısından olumlu bulunmuştur. Yapıdaki çatı izolasyonu uygulamasının uygunsuz sıcaklık ve bağıl neme karşı alınan bir önlem olmasının yanında (Görsel 12) tarihi yapıdan müzeye dönüştürülürken var olan dış duvarların korunmas aşamasında yalıım malzemesi kullanılmaması koruma ilkeleri açısından doğru ancak yalıtım açııından yetersizdir. Müze idaresi tarafından düzenli olarak bakım ve onarım sağlandığı tespit edilmiştir. Bu şekilde uygunsuz sıcaklık ve bağıl nem değerlerinin yapı malzemeleri üzerindeki etkisinin düzenli olarak kontrolünün sağlandığı ve zararlı etkilerinin giderildiği bilgis müze personeli ile yapılan görüşmelerden edinilmiştir (Doğruer, 2021).

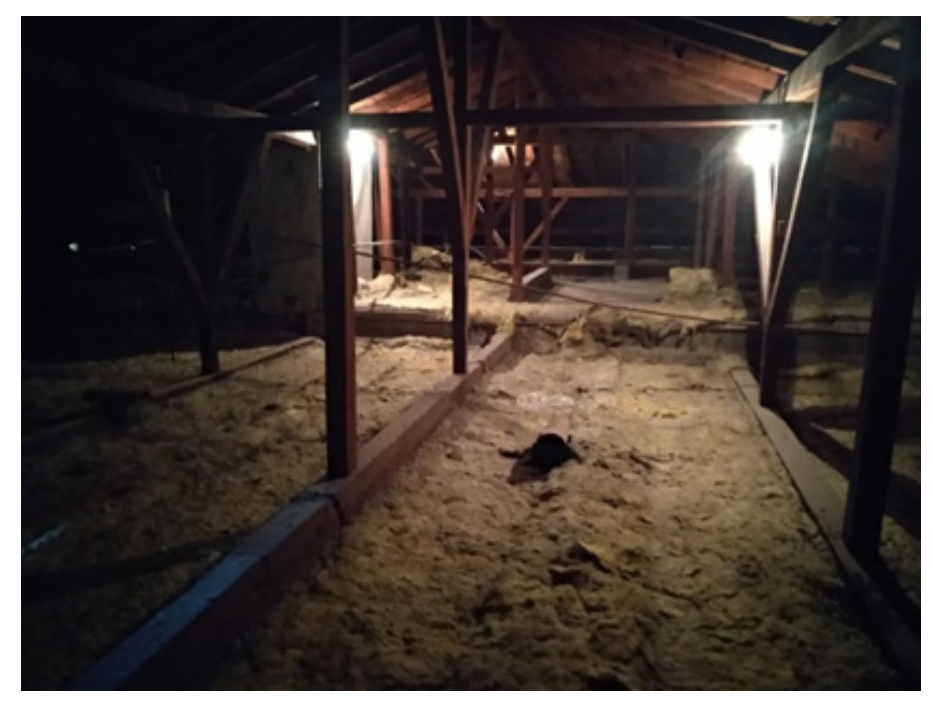

Görsel I2. Çatı izolasyonu (ÇMM, 202I)

\begin{tabular}{|c|c|c|c|c|c|}
\hline $\begin{array}{l}\text { Tehlike } \\
\text { Kay- } \\
\text { nẵı }\end{array}$ & Tehlike & $\begin{array}{l}\text { Tarihi Yapida Tehlike } \\
\text { Oluşturabilecek Etkenler }\end{array}$ & $\begin{array}{l}\text { Kon } \\
\text { trol }\end{array}$ & Müze Yapısı için Alınan Önlemler & $\begin{array}{l}\text { Kon } \\
\text { trol }\end{array}$ \\
\hline \multirow{17}{*}{$\begin{array}{l}\text { Müze- } \\
\text { nin } \\
\text { konu- } \\
\text { mu }\end{array}$} & \multirow[t]{2}{*}{ Deprem } & Toprağın yumuşak / gevsek olması & $\frac{\mathrm{x}}{\mathrm{y}}$ & \multirow{2}{*}{$\begin{array}{l}\text { Zeminde jeolojik ölçümler yapilmass; } \\
\text { gerekiyorsa zeminin güçlendirilmesi }\end{array}$} & \multirow[t]{2}{*}{$\mathrm{x}$} \\
\hline & & $\begin{array}{l}\text { Sismik hareketin yüksek olmas1 } \\
\text { Deprem bölgesinde ver almas1 }\end{array}$ & $\frac{x}{x}$ & & \\
\hline & Hirsızllik/ & Suç işleme bakımindan yüksek & $\mathrm{x}$ & *Güvenlik sistemlerinin kurulumu & $\sqrt{1}$ \\
\hline & $\begin{array}{l}\text { Vanda- } \\
\text { lizm }\end{array}$ & orana sahip bölge & & ${ }^{*}$ Güvenlik personelinin görevlendirilmesi & \\
\hline & \multirow[t]{3}{*}{ Yangin } & Çevrede yangın riski taşıyan binalar & $\mathrm{x}$ & $\begin{array}{l}\text { "Manuel / Otomatik yangin söndürme } \\
\text { sistemi kurulumu } \\
\text { "Merkezi izlemeye sahip duman / 1s1 } \\
\text { tespit sistemleri kurulumu }\end{array}$ & \\
\hline & & 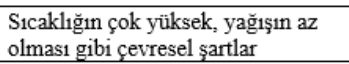 & $\mathrm{x}$ & Ist izolasyonu yapilmass & $\mathrm{x}$ \\
\hline & & Suç oranınin yüksek olması & $\mathrm{x}$ & Güvenlik sistemi kurulumu & I \\
\hline & \multirow{3}{*}{$\begin{array}{l}\text { Su } \\
\text { Baskinı }\end{array}$} & Dere yatağı & $\mathrm{x}$ & \multirow[t]{2}{*}{ Drenaj sistemi kurulumu } & \multirow[t]{2}{*}{$\sqrt{ }$} \\
\hline & & $\begin{array}{l}\text { Yağmur ve kar yağış miktarının } \\
\text { fazlalığı veya değisken olması }\end{array}$ & $\mathrm{x}$ & & \\
\hline & & $\begin{array}{l}\text { Geçmişte yaşanmis şiddetli } \\
\text { meteorolojik olaylar }\end{array}$ & $\sqrt{ }$ & $\begin{array}{l}\text { Geçmissteki bu tür siddetli meteorojik } \\
\text { olaylarn incelenmesi ve tekrarlamast } \\
\text { olası zaman diliminin belirlenmesi }\end{array}$ & $\mathrm{x}$ \\
\hline & $\begin{array}{l}\text { Yer } \\
\text { Kaymas1 }\end{array}$ & $\begin{array}{l}\text { Toprağin yumuşak / gevşsek olması } \\
\text { Hevelan bölgesi }\end{array}$ & $\frac{x}{x}$ & $\begin{array}{l}\text { Zeminde jeolojik ölçümler yapılmast; } \\
\text { gerekivorsa zeminin güclendirilmesi }\end{array}$ & $\mathrm{x}$ \\
\hline & \multirow{3}{*}{ Kirlilik } & Endüstriyel alan & $\mathrm{x}$ & \multirow{3}{*}{$\begin{array}{l}\text { "Filtre kullanımı } \\
\text { *Kirletici kaynaklarnndan uzak hava girişi }\end{array}$} & \multirow{3}{*}{$\begin{array}{l}\mathrm{X} \\
\mathrm{x}\end{array}$} \\
\hline & & Yoğun Trafik & 1 & & \\
\hline & & Döşenmemiş Yollar & $\mathrm{x}$ & & \\
\hline & $\begin{array}{l}\text { Uygunsuz } \\
\text { Sicaklik }\end{array}$ & Uygunsuz mevsimsel şartlar & $\mathrm{x}$ & Uygun yalittm malzemesi kullanım1 & $\mathrm{x}$ \\
\hline & \multirow{2}{*}{$\begin{array}{l}\text { Uygunsuz } \\
\text { Bağı1 } \\
\text { Nem }\end{array}$} & Yağmurlu iklim koşulları & $\mathrm{x}$ & \multirow{2}{*}{$\begin{array}{l}\text { "CCatt izolasyonu } \\
\text { "Uygun yalitim malzemesi kullanimı } \\
\text { "Bakim onarım }\end{array}$} & \multirow{2}{*}{$\begin{array}{l}y \\
x \\
y\end{array}$} \\
\hline & & $\begin{array}{l}\text { Yaknn cevrede yer alan su } \\
\text { kavnakları }\end{array}$ & $\mathrm{x}$ & & \\
\hline
\end{tabular}

Tablo I. Tarihi Yapının Çorum Müzesine Dönüştürülmesine Yönelik Müze Konumu Kaynaklı Tehlike/Önlem Değerlendirme Tablosu 


\section{Tarihi Yapının Çorum Müzesine Dönüştürülmesine Yönelik Müze} Yapısından Kaynaklı Tehlike ve Önlemlerin Değerlendirilmesi

Çorum Müzesi yapısından kaynaklanan tehlikeler ele alındığında, öncelikle deprem ve temas, darbe, titreşim ve benzeri fiziksel kuvvetler tehlikesi yönünden değerlendirme yapılacaktır. Müze yapısının depreme karşı dayanıklılı̆̆ına yönelik testlerin yapılmadığı düşünüldüğünde yapının güçlendirilmesinin gerekip gerekmediği hakkında yorum yapmak uygun değildir. Temas, darbe, titresim gibi eserlerde bozulmaya sebep olabilecek etkenler mekân zeminlerinin ve geçişlerinin düz olmaması, sergileme mekânı olacak mekânların yeterli genișlikte olmaması durumlarında ortaya çıkabilmektedir. Çorum Müzesi mekânları ve geçişleri olumlu şartları sağlamaktadır. Müzedeki teşhir düzenlemelerinin mekân zeminleri ve geçişlerinin eserlere yönelik bir tehlike oluşturmadığı; depolama alanlarında yedek depo bulunduğu; sergileme mekânlarının mevcut haliyle ihtiyacı karşıladığı ancak koleksiyonun büyümesine durumunda yeni bir teșhir düzenlemesine ihtiyaç duyulabileceği belirlenmiştir. Müzenin tarihi yapı olması sebebiyle yapıda düşey sirkülasyonu sağlayacak mevcut merdivenler yerine eser taşınmasına uygun rampa yapma olanağı bulunmamaktadır. Bunların yanında, deprem tehlikesi kültür varlıklarında birincil ve ikincil riskler oluşturabildiğinden (Şener ve Yılmaz, 2020: 21), deprem sonrasında gelebilecek diğer risklere yönelik olarak elektrik sisteminin ve gaz vanalarının kontrol edilmesi yerinde olacaktır (Ertürk, 2010: 51). Ayrıca, depreme yönelik bir önlem olarak daha çok yurtdışı örneklerinde görülen zemine sismik taban izolatörü uygulamalarının (Kanada Koruma Enstitüsü, 2015), tarihi yapı rekonstrüksiyon çalışmalarında da kullanılabileceği düşünülmektedir.

Hırsızlık ve vandalizme yönelik olarak müze yapısında risk oluşturabilecek bir etken tespit edilmemiştir. Müze, sağlam bahçe ve bina duvarları ile kapı ve pencerelere sahiptir, gece aydınlatmasının bulunduğu, iç mekânlar için giriş ve çıkışının görülebildiği bir görüş alanının olduğu gözlemlenmiştir. Ayrıca mekân güvenliği için önlem olarak güvenlik odası, CCTV odası ve güvenli bir yükleme alanları oluşturulmuş, giriş holü ile Arkeoloji Seksiyonu arasında gerektiğinde kapanabilen kontrollü bir geçiş uygulaması yapılmıştır. Eserler üzerinde araștırma, paketleme, fotoğraf çekimi gibi çalıșmaları laboratuvarda yapılmaktadır; bu şekilde depodaki eserle üzerinde depo dışında bir alanda çalışıması ile güvenlik sağlanmaktadır.

Yangın tehlikesine yönelik tarihi yapıda karşılaşılan sorunlar arasında yangına dayanıksız yapı malzemesi kullanımı, yangın çıkması durumunda bina içinde yangının yayılımı, elektrik sistemindeki bozukluklar müzeye dönüstürülmeden önce karşılaşılan olumsuzluklardır. Nitekim müze 1988 yılında geçirdiği yangın sebebiyle büyük hasar görmüş, iç duvar ve döşemeleri kullanılamaz duruma gelmiştir. Müzeye dönüştürülürken alınan önlemler olarak, yeni yapım sisteminin yangına dayanıklı çelik sistem ile yapılandırılması, doğrudan dışarıya açılan yangın çıkış kapıları kullanılması, kablo ve elektrik sistemlerinin 2019 yllında yenilenmesi ve 2020 yılında manue yangın söndürme sistemi kurulumu sıralanabilir. Yanıcı maddelerin laboratuvarda kilitli dolapta depolandığı tespit edilmiştir. Mekânlar arasında hava sızdırmazlığının bulunmaması ve depo mekânı kapılarının yangın kapısı özelliğinde olmaması yangın tehlikesine yönelik olumsuz yanlar olarak belirtilebilir.

Müze yapısından kaynaklanan su baskını tehlikesi, çatı ve tavandan su akması, su sızdıran penceler, bodrum kattaki teknik hacimlerde ve sıhhi tesisatta arıza ile su toplanmasına neden olabilecek yerler gibi sebeplerle oluşabilmektedir (Kanada Koruma Enstitüsü, 2015). Çorum Müzesinde eğimli çatı, saçak, yağmur oluğu kullanımı, çatıda izolasyon, depolama mekânlarının en üst katta yer almaması ve su baskınında kullanılacak ekipman için mekân bulunması su baskını tehlikesine yönelik müze yapısındaki önlemlerdir. Bunların yanı sıra, sıhhi tesisat sistemi 2019 yılında yenilenmistir ve sergileme ve depolama mekânlarında sıhhi tesisat bulunmamaktadır. Depolama mekânlarının yanında veya aynı hizasında üst katta ıslak mekân bulunmamaktadır. Müze tuvaletlerinin bahçe içerisinde yer altında ve ana kültleden uzakta düzenlendiği (Görsel 13). Depoların bodrum katta yer alması sebebiyle kazan dairesi, su dağıtım sistemi gibi mekânlarda olusabilecek arızalarda eserlerin sudan etkilenme riski oluşabilecektir. Buna yönelik olarak, mekanik ekipman odasında fazla suyun tahliyesi amacıyla zemine mazgal yapıldığı tespit edilmiştir. Temizlik görevlilerince sürekli bakımının yapılması ile su giderlerinde tıkanmalara karşı önlem alınmış olmaktadır (Roberts ve Hutchins, 2009/2016: 19).

Müze yapısında bir zararlı (böcek, hayvan vb.) tehlikesine sebep olabilecek etkenler olan yeterli temizlik yapılmaması, yapı içinde atık bulundurulması, temizliğe engel mekânlar Çorum Müzesi için geçerli değildir. Müzenin açık ve kapalı mekânlarında düzenli temizlik ve ilaçlama yapılmaktadır. Müze içerisinde yeme içme mekânı, sergileme alanlarında erişilemeyen alanlar bulunmamaktadır. Bu şekilde böceklerin yuva yapması da önlenmektedir. Açılabilir pencerelerdeki parmaklık sayesinde yapı içine hayvan girmesi engellenmektedir. Teşhirde kullanılan malzemelerinin zararılıar için yemek kaynağı olabileceği görülmüş, buna yönelik olarak malzemelere periyodik bakım yapıldığı öğrenilmiştir (Doğruer, 2021). Yine de, böceklenme tehlikesine karşı sergilemelerde kuru yiyeceklerin imitasyonlarının kullanımı yerinde olacaktır. 


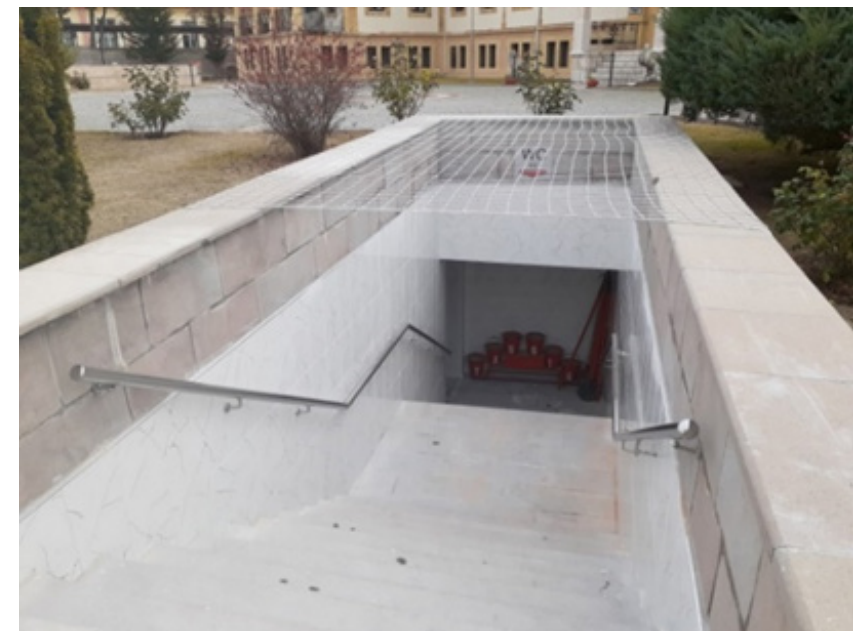

Görsel I3. Bahçe içerisinde yer altı tuvaletleri (ÇMM, 202I)

Müze binası kaynaklı kirlilik tehlikesi yönünden inceleme yapıldığında kullanılan yapı veya dekorasyon malzemelerinin kirletici madde yayılımı yapmadığı ve diğer mekânlara kirletici dağılımı olmadığı belirlenmiştir. Giriş holü ve fotoselli kapı ile kontrollü geçiş sayesinde olası kirleticilerin dış mekândan sergileme mekânlarına doğrudan erişimi sınırlandııımaktadır. Bununla beraber, müze mekânlarının kir, toz, yangın durumunda oluşabilecek duman gibi kirleticilerin diğer mekânlara erişimini kısıtlayacak şekilde hava sızdırmaz olmadığı açıktır, nitekim ziyaretçi sirkülasyonu olan bu tür alanlarda bunun sağlanması beklenemez, ancak kirliliğin sınırlandırılmasına yönelik olarak müze giriş ve yükleme kapılarının kapalı tutulması uygun olacaktır.

Müzelerde sergileme ve depolama için kullanılacak mekânlarda pencere bulunması eserler için uygunsuz ışı tehlikesine sebep olmaktadır. Bu yüzden yapı müzeye dönüstürülürken asma kattaki sergi salonundaki pencereler paneller ile, zemin kattaki sergi salonundaki pencereler ise perdeler ile kapatıımıştır. Müze yapısında uygunsuz ısı̆ğa karşı, genel aydınlatma yerine bölümlere ayrı aydınlatma tasarlanması, depolarda isteğe bağlı aydınlatma kullanılması, eserlere zarar vermeyen aydınlatma kullanılması gibi önlemler alınmışıı. Güvenlik ve bakım için farklı aydınlatma devreleri kullanımı uygunsuz ışığa yönelik alınabilecek başka bir önlemdir.

Eserler için uygunsuz sıcaklık tehlikesi, bina içerisinde olması gerekenden çok yüksek, çok düşük veya değişken sıcaklık oluşması nedeniyle ortaya çıkmaktadır. Buna yönelik alınması gereken önlemler, mekânlarda sıcaklık ölçer kullanımı, belirlenen limitin dışına çıkıldığında bildirim alınması ve iklimlendirme cihazlarına komut verilmesi olarak sıralanabilir. Eser bulundurulan mekânlarda sıcaklığın 18-20oC aralı̆ıında tutulması gerekmektedir (Milli Park Hizmeti, 2006: 9) Müzenin arkeolojik eser sergileme mekânı yerden ısıtma sistemi ile ısıtılmaktadır; etnografik eser sergileme mekânı ile diğer mekânların ısıtması ise kalorifer sistemi ile sağlanmaktadır. Belirlenen sıcaklık değerleri otomatik kombi sistemi ile sabit tutulmaktadır (Görsel 14) (Doğruer, 2021). Bunlara ilaveten yükleme alanının kapalı tutulan bir mekân olması sayesinde buradan sergileme ve depolama mekânlarına olası uygunsuz sıcaklık yayılımının kontrolü sağlanmaktadır. Sıcaklık kontrolü açısında olumsuz bir yan olarak pencerelere çoklu cam bulunmamaktadır.

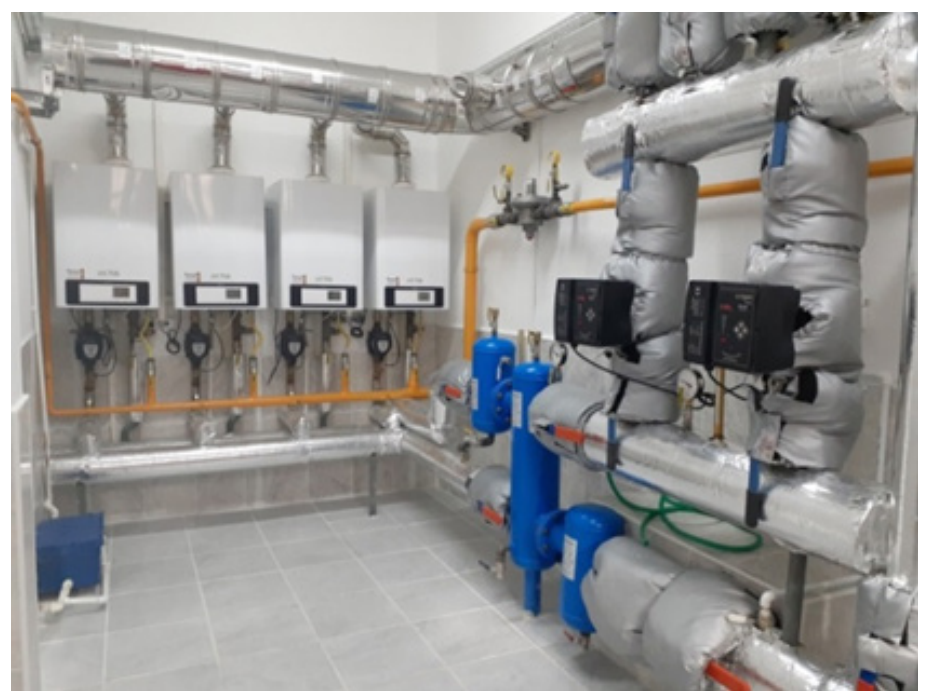

Görsel I4. Isıtma sistemi (ÇMM, 202I)

Eserler üzerinde uygunsuz bağıl nem tehlikesi, bina içerisinde olması gerekenden çok yüksek, çok düşük veya değişken bağıl nem olması; tarihi yapının dış duvarı içindeki su hareketine engel olacak malzeme kullanımı; ısıtma sisteminde arıza meydana gelmesi nedenleriyle ortaya çıkmaktadır (Kanada Koruma Enstitüsü, 2015). Tarihi yapı restorasyonunda özgüne benzer özellikte taş, harç ve sıva malzemeleri kullanımı ile duvar içerisindeki olası nemin dış ortama aktarılması sağlanmaktadır. Isıtma sistemlerinin düzenli bakımı ile bağıl nem kontrolünün sergileme ve depolama mekânlarında sağlanmış olması alınan önlemlerdendir. Tarihi yapılarda nem oranının yükseldiğini gösteren duvarın kararması, sıvanın kabarması, sıvanın dökülmesi gibi işaretler varlığında etkin korumaya yönelik tedbir- 
ler alınmalı, eserler restorasyon bitene kadar başka bir alana taşınmalıdır (Kökten, 2007: 60). Tarihi yapıda özgün duvar yapısına yalıtım ve buhar tutucu malzemelerin uygulanması mümkün olmadığından uygunsuz bağıl neme yönelik iç mekân kontrolü çeşitli cihazlarla sağlanmalıdır. Sergileme mekânlarında bağıl nem cihazı kullanıldığı, ancak düşük bağıl nemin vitrinlerde gevrekleşmeye neden olduğu gözlenmiştir. Müzedeki eser türlerine göre, bağıl nemde kabul edilebilir değerlerin belirlenmesi ve bunlara müdahale edilmesi laboratuvar çalışanlarınca yapılmalıdır (Doğruer, 2020: 31). Nem alma cihazının kullanımında kontrolün koruma uzmanlarınca sağlanması önemlidir. Müzedeki risk etkenlerinin iç mekânlara etki etme derecesinin tespiti koruma uzmanlarınca yürütülecek izleme calışmaları ile mümkün olacaktır (Kuzucuoğlu, 2010: 17). Bununla birlikte, eserlerin cam, soğuk zemin ve dış duvarlardan belirli uzakta yerleştirildiği belirlenmiştir.

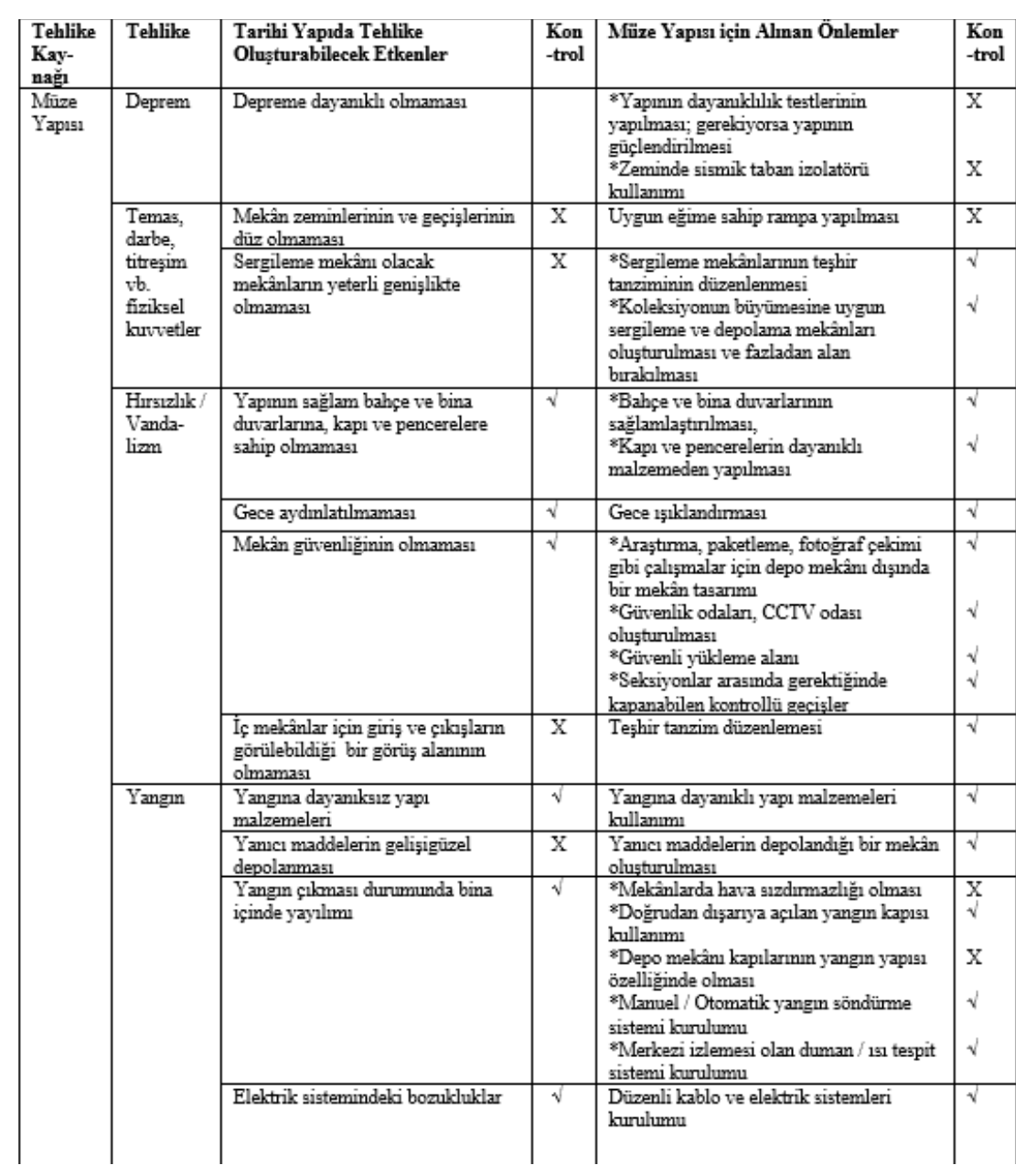

\begin{tabular}{|c|c|c|c|c|}
\hline \multirow[t]{5}{*}{$\begin{array}{l}\text { Sulim } \\
\text { Hoskin }\end{array}$} & Catse lavandian sa akmasi & $\mathrm{x}$ & 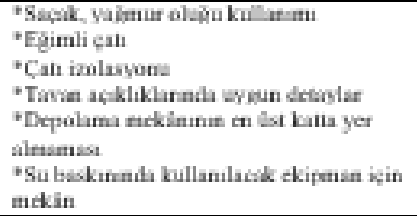 & $\checkmark$ \\
\hline & 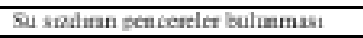 & $\mathrm{X}$ & "Lyphun desablit & v \\
\hline & 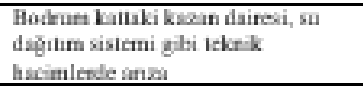 & 8 & 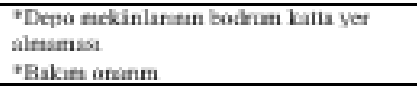 & $\overline{\mathrm{x}}$ \\
\hline & 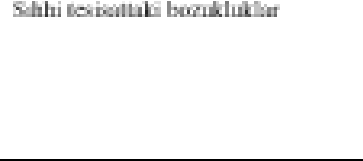 & 8 & 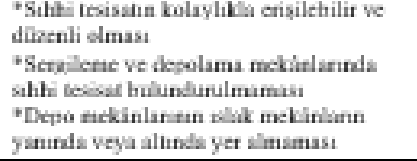 & $\begin{array}{l}\sqrt{v} \\
\sqrt{ }\end{array}$ \\
\hline & 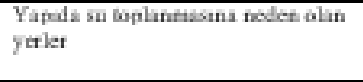 & $\mathrm{x}$ & 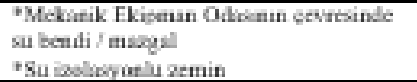 & $\mathrm{v}$ \\
\hline \multirow[t]{6}{*}{$\begin{array}{c}\text { Zariath } \\
\end{array}$} & 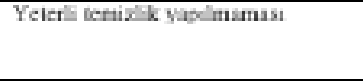 & $\mathrm{x}$ & 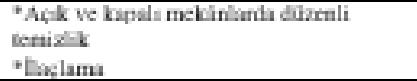 & 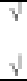 \\
\hline & 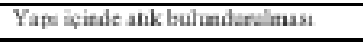 & $\mathrm{x}$ & 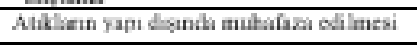 & $\nabla$ \\
\hline & 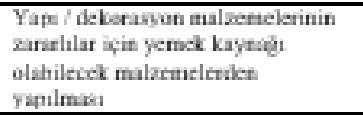 & 8 & 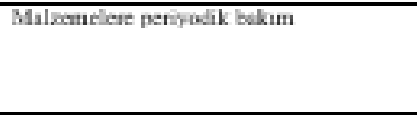 & $\bar{v}$ \\
\hline & 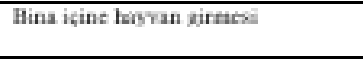 & $\mathrm{x}$ & 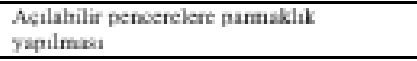 & $\nabla$ \\
\hline & 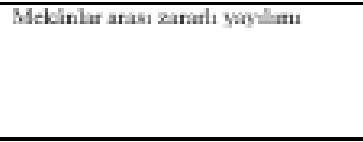 & $\mathrm{x}$ & 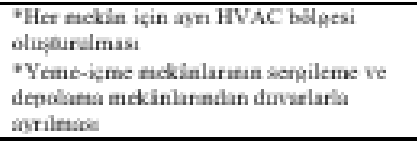 & $\begin{array}{l}\mathrm{x} \\
\mathrm{x}\end{array}$ \\
\hline & Temialike entel mekiniat & $\mathrm{x}$ & 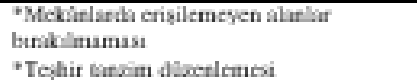 & $\mathrm{v}$ \\
\hline \multirow[t]{3}{*}{ 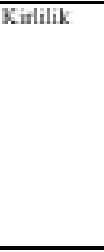 } & 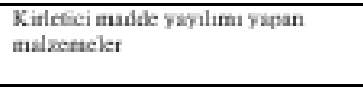 & $\mathrm{x}$ & 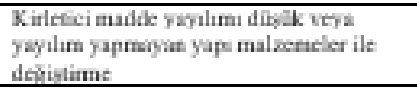 & $\bar{x}$ \\
\hline & 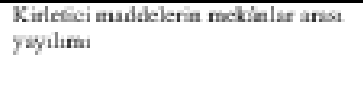 & $\mathrm{x}$ & 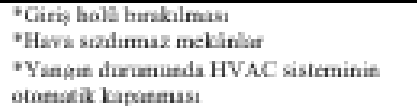 & $\begin{array}{l}\mathrm{v} \\
\mathrm{x} \\
\mathrm{x}\end{array}$ \\
\hline & 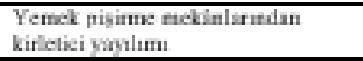 & $\mathrm{x}$ & Favalandirats sistemi Kuruluetu & $\overline{\mathrm{x}}$ \\
\hline \multirow[t]{2}{*}{$\begin{array}{l}\text { Dypumsuz } \\
\text { lyak }\end{array}$} & 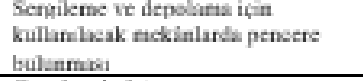 & $\gamma$ & 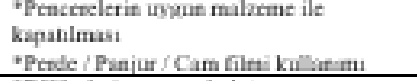 & $\sqrt{v}$ \\
\hline & Genel indulinhimi & $\mathrm{x}$ & 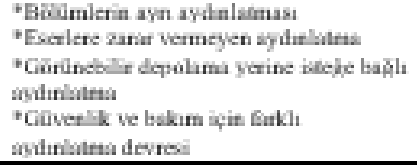 & $\begin{array}{l}v \\
v \\
\mathrm{v}\end{array}$ \\
\hline $\begin{array}{l}\text { Dypunsuz } \\
\text { Secallak }\end{array}$ & 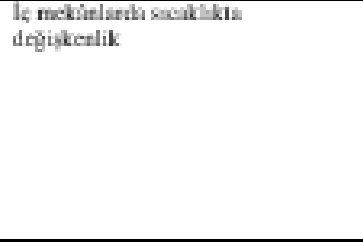 & 8 & 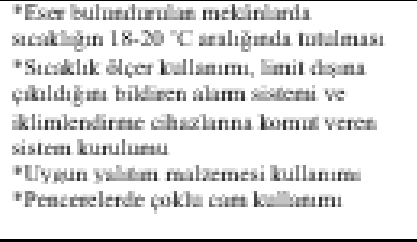 & $\sqrt{ }$ \\
\hline
\end{tabular}




\begin{tabular}{|c|c|c|c|c|}
\hline & & & 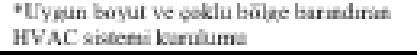 & \\
\hline & 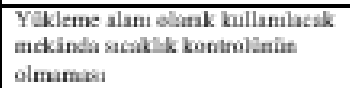 & $\checkmark$ & 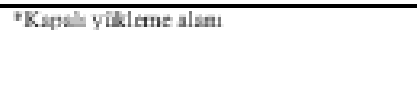 & $\sqrt{5}$ \\
\hline \multirow[t]{3}{*}{ 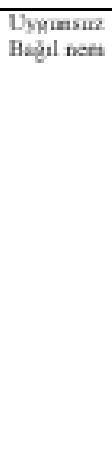 } & 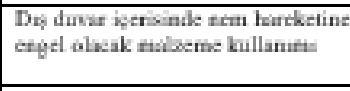 & $\mathrm{x}$ & 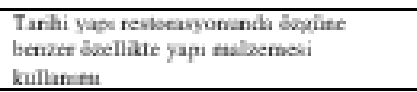 & $\nabla$ \\
\hline & 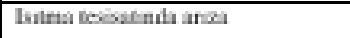 & $\nabla$ & 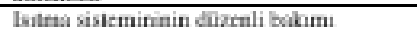 & $\sqrt{2}$ \\
\hline & 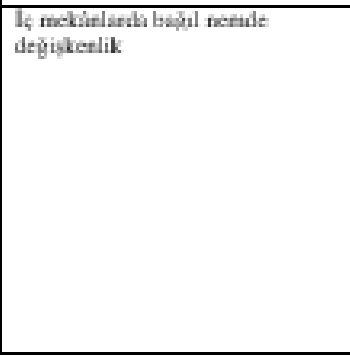 & $\gamma$ & 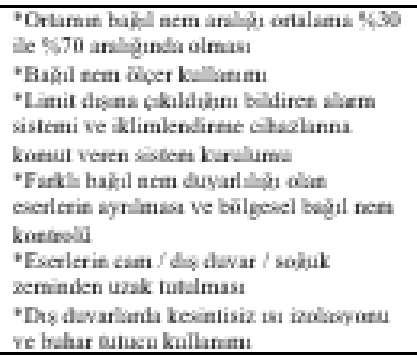 & 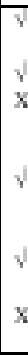 \\
\hline
\end{tabular}

Tablo 2. Tarihi Yapının Çorum Müzesine Dönüştürülmesine Yönelik Müze Yapısı Kaynaklı Tehlike/Önlem Değerlendirme Tablosu

\section{Sonuç}

Zaman içinde gelişen ve değişen koruma ve müzecilik anlayışına göre tarihi yapıların müze olarak düzenlenmesi sırasında gerçekleştirilen uygulamalar da değismelidir (Doğruer, 2019: 131). Müzelerde karsılasıılan tehlikeler, eser ve bina sağlığı yönünden çeşitli risklere yol açmaktadır. Bu tehlikeler müzenin konumundan ve müze yapısından kaynaklanabilmektedir. Tarih yapıların restorasyon çalışmalarında ve müzeye dönüştürmeye yönelik düzenlemelerde, oluşabilecek tehlikeler için alınabilecek önlemler ile eserler için gerekli koruma sağlanabilecektir. Tarihi yapıdan müzeye dönüştürülen örneklerde kültür varlığına yapılan müdahalelerin kısıtı olması gerçeği ve farklı bir kullanım amacına göre tasarlanan biryapının müzecilik kullanımına göre yeniden düzenlenmesinin gerektiği Çorum Müzesinde de aşikardır.

Tarihi yapının Çorum Müzesine dönüştürülmesi sırasında ortaya çıkabilecek tehlikelere yönelik yapılan tespitler, tehlike kaynakları, tehlike türleri ve bunlara karşı alınan önlemler açılarından incelenerek elde edilmiştir. Müzeye dönüştürme çalışmalarında tehlikelere karşı önlemlerin büyük ölçüde yerine getirildiği görülmekle birlikte halen eksiklikler olduğu belirlenmiştir. Müzedeki eserlerin yanı sıra, müze olarak kullanılan tarihi binaların da bir eser gibi düşünülerek korunması gerektiği göz ardı edilmemelidir (Kökten, 2007: 59).
Müze kurulum aşamasında sadece yapının kendisinden kaynaklanacak tehlikeler değil, konumun getireceği tehlikeler de değerlendirilmelidir. Buna yönelik olarak, eski bir dere yatağındaki binanın su baskını yönünden, heyelan bölgesindeki binanın ise toprak kayması yönünden risk barındırdığı; suç işleme oranı yüksek bir mahallede konumlandııılmış müzenin hırsızlık vandalizm ve yangın yönünden risk taşıdığl; endüstriyel alandaki bir binanın kendisi ve eserleri için kirlilik tehlikesi taşıdığı, müze binasının deprem bölgesinde yer aldığı veya binanın oturduğu toprağın yumuşak ve gevşek olduğu durumlarda mutlaka zemin ölçümlerinin ve gerekiyorsa güçlendirmesinin yapılması gerektiği, çevresel şartların binada uygunsuz sıcaklık ve bağıl neme sebep olabileceği gibi birçok örnek verilebilir.

Hazırlanan tehlike ve önlem değerlendirme tabloları ile tarihi yapıda risk olusturabilecek tehlikeler, tehlike kaynaklarının tespiti ve bunlara yönelik alınan/alınması gereken önlemler ilişkilendirilmesi yapılarak ileriki çalışmalarda kolaylık sağlayacak bir yöntem ortaya çıkarılmışır. Müze idaresi ve müzeye dönüştürme çalışmalarında görev alan ekip tarafından kullanılabilecek değerlendirme tabloları ile tarihi bina ve eser sağlığına yönelik risklerin en aza indirgenmesi amaçlanmaktadır.

Müzecilik fonksiyonuna yönelik Çorum Müzesinde yapılması gereken düzenlemeler arasında müzeye gelecek yeni eserlerin zararılı barındırmas intimaline karşı, eser inceleme, karantina ve zararlı mücadelesine yönelik bir mekân tasarlanmalıdır. Müzeye dönüştürüldüğü tarihten sonra sergilemeye yönelik yeni bir düzenleme yapılmamış olan müzede günümüz intiyaçlarının düşünülerek sergilemeye yönelik yenilemelerin yapılması ihtiyacı da kaçınılmazdır. Tarihi yapılarda minimum müdahale ve koruma ilkelerine uygunsuz olmayacak şekilde çağdaş teknik ve tasarımlar ile projelendirmeler yapılması ile korumada başarılı sonuçlara ulaşılacaktır. 


\section{Kaynakça}

Çorum Müzesi Müdürlüğ̈̈. (202I, 22 Ocak). Çorum Müzesi Dijital Arşivi. Ankara.

Doğruer, F.S. (2019). "Müzelerde Önleyici Koruma: Temel Yaklaşımlar ve Gelişimi", Akademik Sanat; Sanat, Tasarım ve Bilim Dergisi, 4 (7), I22-I34.

Doğruer, F. S. (2020). Müze Tasarımları İçin Önleyici Koruma Kılavuzu. Ankara: ICOM Türkiye Yayınları.

Doğruer, F.S. (202I, 22 Ocak). Çorum Müzesi Müdürü Metin Çakar ile Yapılan Görüşme. Çorum Müzesi, Çorum.

Doğruer, F.S. (202I, 22 Ocak). Çorum Müzesi Personeli ile Yapılan Görüşme. Çorum Müzesi, Çorum.

Doğruer, F.S. (202I , 27 Ocak). T.C. Çorum Valiliği, Çevre ve Şehircilik Müdürlüğ̈̈ Ile Yapılan Telefon Görüsmesi.

Ertürk, N. (20I0). Deprem. W. Hekman. (Editör) Müzeler İçin Acil Durum Prosedürleri EI Kitabı (çev. B. Gündaş).ICOM, International Committee on Museum Security, Müzecilik Meslek Kuruluşu Derneği, s. 47-52.

Kadıŏ̆lu, M. (2008). Modern, Bütünleşik Afet Yönetimin Temel IIlkeleri. Kadıŏ̆lu, M. ve Özdamar, E. (Editörler). Afet Zararlarını Azaltmanın Temel IIlkeleri, Ankara: JICA Türkiye Ofisi Yayınları, s. I-34

Kanada Koruma Enstitüsü. (2015). Framework For Preserving Heritage Collections Poster. Kanada.

Kocaeli, F . (20I7). “iç Anadolu Bölgesi Müzelerinde Önleyici Koruma Sorunları Üzerine Bir Değerlendirme”, Restorasyon ve Konservasyon Çalışmaları Dergisi, (20), 52-64.

Kökten, H. (2007). Müzede Koruma. B. Eskici, S. Çelik, D. Hepdinç, H. Kökten, ve Y.S. Şener (Editörler). Müzelerde Önleyici Koruma Uzaktan Eğitim Programı. Ankara: Ankara Üniversitesi Uzaktan Eğitim Yayınları.

Kültür Varlıkları ve Müzeler Genel Müdürlüğü (202I, Şubat). Kültür Varlıkları ve Müzeler Genel Müdürlüğü Arşivi. Ankara.

Kuzucuoğlu, A. H. (2010). “Müzelerde İklim Ölçümlerive Pasif Konservasyon”, RestorasyonKonservasyon Çalışmaları Dergisi, (6), I7-22.

Milli Park Hizmeti, (2006). Müzecilik El Kitabı, Part I, A.B.D.: Milli Park Hizmeti.
Roberts B.O. ve Hutchins, J.K. (2009/2016). Müzeler İçin Afet Risk Yönetimi. Kültürel Mirasını Koruma El Kitabı 4 (çev. M. Aydın). Paris: UNESCO.

Sener, Y. S. ve Yılmaz, S. (Editörler). (2020). Müzelerde Afet Risklerinin Azaltılması Kılavuzu 2020. İstanbul: Kültürel Mirasın Dostalrı Derneği.

T.C. Içişleri Bakanlığı, Afet ve Acil Durum Yönetimi Başkanlı̆̆ı. (20l4). Açıklamalı Afet Yönetimi Terimleri Sözlüğü. Ankara: Afet ve Acil Durum Yönetimi Başkanlığı.

Zıvralı, I. ve Cabbar, Ü.N. (20I5). "Kültür Varlıklarında Risk Yönetimi; Gelişimi, Güncel Durum ve Öneriler" 5.Tarihi Eserlerin Güçlendirilmesi ve Geleceğe Güvenle Devredilmes Sempozyumu (I-3 Ekim 20/5) (Cilt 2) (s. I55- I 70), Inșaat Mühendisler Odası, Ankara.

\section{Internet Kaynakları}

internet: Çorum Haritası.

https://tr.wikipedia.org/wiki/\%C3\%87orum_M\%C3\%BCzesi\#/map/0 adresinden 18 Mayıs 202I'de alınmıştır.

Internet: Çorum İline Ait Mevsim Normalleri, T.C. Tarım ve Orman Bakanlı̆̆ı, Meteoroloji Genel Müdürlügü. Web: https://mgm.gov.tr/veridegerlendirme/il-ve-ilceler-istatistik. aspx?k= undefined\&m = CORUM adresinden 26 Ocak 202I'de alınmıştır.

Internet: T.C. Çorum Valiliği resmi internet sitesi. Web: http://corum.gov.tr/corum-muzesi adresinden II Şubat 202 I'de alınmıştır.

Internet: Türkiye Deprem Tehlike Haritası. T.C. İçişleri Bakanlığı, Afet ve Acil Durum Yönetimi Başkanlığı. Web: https://deprem.afad.gov.tr/deprem-tehlike-haritasi adresinden 25 Ocak 202I'de alınmıştır.

\section{Görsel Kaynakları}

Görsel I. Çorum Müzesi'nin kentsel konumuna ilişkin harito

Internet: Çorum Haritası. https://tr.wikipedia.org/ wiki/\%C3\%87orum_M\%C3\%BCzesi\#/map/0 adresinden I8 Mayıs 202I'de alınmıştır.

Görsel 2. Yangın sonrası müzenin görünümü

Çorum Müzesi Müdürlüğü. (202I, 22 Ocak). Çorum Müzesi Dijital Arşivi. Ankara.

Görsel 3. Yangın sonrası müzenin görünümü (Çorum Müzesi Müdürlüğ̈̈ [ÇMM], 202I) 


\section{Görsel 4. Müze giriş katı plan şeması}

Görsel 5. Sergileme mekânında asma kat

Görsel 6. Depolar ve Etnografya Seksiyonu

Çorum Müzesi Müdürlüğü. (202I, 22 Ocak). Çorum Müzesi Dijital Arşivi. Ankara.

Görsel 7. Depolar ve Etnografya Seksiyonu (ÇMM, 202I)

Görsel 8. Depo mekânı

Çorum Müzesi Müdürlüğ̈̈. (202I, 22 Ocak). Çorum Müzesi Dijital Arşivi. Ankara.

Görsel II. Çatı izolasyonu

Çorum Müzesi Müdürlüğ̈̈. (202I, 22 Ocak). Çorum Müzesi Dijital Arşivi. Ankara.

Görsel I2. Bahçe içerisinde yer altı tuvaletleri

Çorum Müzesi Müdürlüğü. (2021, 22 Ocak). Çorum Müzesi Dijital Arşivi. Ankara.

Görsel I3. Isıtma sistemi

Çorum Müzesi Müdürlügü̈. (202I, 22 Ocak). Çorum Müzesi Dijital Arşivi. Ankara. 